\title{
Onfarm Validation of Agricultural Technologies for Supporting Tef Extension Package Formulation in Ethiopia
}

\author{
Yazachew Genet ${ }^{1,}$, , Aklilu Nigussie ${ }^{1}$, Tsion Fikre ${ }^{1}$, Kebebew Assefa ${ }^{1}$, Rehima Musema ${ }^{2}$ \\ ${ }^{1}$ Ethiopian Institutes of Agricultural Research, Debre-Zeit Agricultural Research Center, Debre Zeit, Ethiopia \\ ${ }^{2}$ Ethiopian Institutes of Agricultural Research, Agricultural Economics Research Directorate, Addis Ababa, Ethiopia
}

Email address:

yazachewgenet@gmail.com (Y. Genet)

${ }^{*}$ Corresponding author

\section{To cite this article:}

Yazachew Genet, Aklilu Nigussie, Tsion Fikre, Kebebew Assefa, Rehima Musema. Onfarm Validation of Agricultural Technologies for Supporting Tef Extension Package Formulation in Ethiopia. International Journal of Applied Agricultural Sciences.

Vol. 6, No. 6, 2020, pp. 172-178. doi: 10.11648/j.ijaas.20200606.12

Received: September 25, 2020; Accepted: October 15, 2020; Published: November 16, 2020

\begin{abstract}
Tef grain yield is low, at $1.75 \mathrm{kgha}^{-1}$ in Ethiopia. Therefore, the objectives of this study were to compare biological superiority of the technology package; to conduct partial budget cost-benefit analysis of the technology and to improve the full package of recommendations. Three interventions packages on the tef production system which are: extension package, Agricultural transformation Agency of Ethiopia package and the research package (row and broadcast planting) application was laid out in a randomized complete block design with the replication (farmers/ locations as replication). The experimental plot size was $500 \mathrm{~m}^{2}$. The result indicates that research package on broadcast planting and raw planting systems were found to be superior in grain yield $1580 \mathrm{kgha}^{-1}$ and $1550 \mathrm{kgha}^{-1}$, respectively. Similarly research row sowing and broadcasting recommendations were gave higher above ground biomass $10167 \mathrm{kgha}^{-1}$ and $10000 \mathrm{kgha}^{-1}$, respectively as compared to the ATA and Extension package practice. Thus, the result revealed that seed rate of $10-15 \mathrm{kgha}^{-1}$ both broad cast and row sowing gives better grain yield and shoot biomass providing the highest return with marginal rate of return, whereas ATA package was found to be the least economically viable treatment having minimum MRR. The partial budget analysis result showed that net returns of treatments extension package, research row planting package and research broadcasting package exceeded the net return of the control- ATA package by Ethiopian birr (EB) (0.32), 1.09 and 1.65, respectively (US\$ $1=$ EB 27.49). The decrease in cost for treatment of extension package relative to the control-ATA package was EB 1.03; the added net benefit from this treatment was EB 0.75 per unit, giving a marginal rate of return of $137 \%$. The decrease in cost of treatment research with row planting package relative to treatment of the control-ATA package was EB 71\%, while the increase in net return was EB 32.6 per unit of production, giving a marginal rate of return on the increased expenditure of $218 \%$. The relative decreasing cost of treatment research tef broadcast planting was EB $60.7 \%$ per unit of production as compared to the control-ATA package, while the increase in net return relative to treatment the control was EB 3.38 for a marginal rate of return of $17.95 \%$. Given the high cost of capital, treatments of the control-ATA and the extension package cannot be recommended as they indicate negative benefit cost ration with $(0.51)$ and $(0.31)$ respectively while 1.09 and 1.65 for research row planting and broadcast planting, respectively yet; the broadcast planting of tef production indicated superior in returns of EB 0.65 for EB 1 invested in the production at small scale level. Considering the lack of appropriate tef row planting at the moment, broadcast planting with 1015 seed rate should be used as tef production package in the country.
\end{abstract}

Keywords: Tef, Partial Budget, Marginal Cost, Benefit Cost Ratio, Yield, Variable Cost

\section{Introduction}

Tef (Eragrostis tef) is the most important cereal crop of Ethiopia. The crop is annually grown on over 3.02 million hectares of land, accounting for about one-third of the total cereal acreage and about one-fifth of the gross cereal grain production in the country [6]. It is grown by about 6.6 million smallholder farmers. Tef offers numerous advantages over the other cereals grown in the country with respect to 
both husbandry and utilization of both the grains and the straw. The crop grows under wider range of ecological conditions from sea level up to 3000 meters above sea level and performs better than the other cereals under adverse and margin-al conditions. Tef constitutes the main daily staple food for over 70 million Ethiopians providing good nutrition for the consumers [11]. Furthermore, tef straw has a much value as the grain because of its use for fodder, bedding and construction material. Thus, it is valued for the quality of grain and fodder that it provides, both of which have a high market price [10].

Tef is a very nutritious cereal grain. Its nutritional content is generally comparable to that of the major world cereals like wheat, barley, rice, maize and sorghum. In fact, it is superior in many aspects particularly in minerals such as iron, calcium, magnesium and zinc. In recent years, tef has become popular as health and performance food in the global market. Since the grains are gluten-free, it is useful as food for humans suffering from gluten protein allergy ailments known as celiac disease $[13,5]$. Its low glycemic index characterized by slow release type starches make it particularly suitable for diabetic people. Moreover, its high iron content is associated with the low prevalence of hookworm [7] and pregnancy related anemia in people consuming tef as staple food. As tef is gluten-free and rich in amino acids and minerals, especially iron and calcium, it is widely marketed in Europe and the USA-in organic stores as well as via the Internet-and appreciated by the Ethiopian communities. In cooperation with American and European institutes, Ethiopia is breeding tef with higher yields-by traditional selection, hybridization, and marker-assisted breeding [9, 3].

As Ethiopia's population is ever increasing, so too will the demand for grain. Moreover, tef is one of the most important crops for Ethiopia's agricultural economy, both in terms of consumption and production [14]. Its high nutritional qualities and the absence of gluten make tef increasingly known even outside Ethiopia, which increases the demand for tef [4]. The area of tef has been increasing gradually from time to time partly because of the general increase in the total cultivated area and partly at the expense of the area of the other cereals. At the same time, both the production and productivity have also increased due to the development of new varieties.

Scientific research on tef was started in 1950's. Over the years commendable achievements have been made with respect to the development of improved technologies involving varieties along with improved management practices, generation of information and promotion of improved technologies. The mean tef yield is lower $(1.58 \mathrm{t}$ ha-1) than other cereal crops such as maize (3.4 t ha-1), sorghum (2.4 tha-1), wheat (2.5 t ha-1), and barley (1.97 t ha-1) [6] and this is far lower than the potential yield of $6 \mathrm{t}$ ha-1 estimated by [12] primarily because of low access to technology/innovations [10]. The need for a new and updated national tef research is felt in order to tackle priority problems of tef through concerted up-to-date research and increase its productivity and production and thereby contribute to the overall agricultural transformation plan of Ethiopia.

Cost of production statistics generally only benefits the data suppliers indirectly through improved policy-making, better administrative decisions and more efficient markets. However, there is also potential for the data supplier, namely the farmers themselves, to reap direct benefits. At the farm level, Cost of production data contributes to improve the economic assessment of farm operation. They allow the producer to question his own operation and to benchmark it against the best practices of farms in the same region with similar characteristics. This, in turn, can lead to better informed decisions at the farm-level and improved market efficiency and performance.

A recommendation is information that farmers can use to improve the productivity of their resources. A good recommendation can be thought of as the practices which farmers would follow, given their current resources, if they had all the information available to the researchers. Farmers may be able to use a recommendation directly, as in the case of a particular variety. Or they may adjust it somewhat to their own conditions and needs, as in the case of a fertilizer level or storage technique. The agronomic data upon which the recommendations are based must be relevant to the farmers' own agro ecological conditions, and the evaluation of those data must be consistent with the farmers' goals and socioeconomic circumstances.

Cost of production statistics provide farm extension workers with evidence to support their training and outreach activities, which helps evaluate an individual farm's management practice against norms for the region. It also allows better targeting to the largest payoffs for their activities, which, in turn, elevates productivity.

Objectives

1. To compare biological superiority of the treatments with full technology package.

2. To conduct cost-benefit analysis of the treatments as well as full technology package.

3. To improve the full package of recommendations by incorporating gainful information derived from treatments.

\section{Methodology}

\subsection{Field Experiment}

Four different packages were taken for comparison of returns these were; Extension Package- which was an old recommendation of the research and it's still applied by Ministry of Agriculture extension system, Agricultural transformation agency (ATA) of Ethiopia system which is the new recommendation, New agronomic research finding of row sowing method recommendation and New research broadcasting recommendations with different seed rate, fertilizer, herbicide, insecticide, and agronomic management system were used as treatments (Table 1). The experiment 
were carried out at five locations (four on farm and one on station) which were used as replication and each plot size of $20 \mathrm{~m} \times 25 \mathrm{~m}\left(500 \mathrm{~m}^{2}\right)$. The variety used was Kora.

\subsection{Data and Methods of Analysis}

Relevant agronomic data were collected from the experimental trial. Primary data on grain yield, above ground biomass and straw was calculated. Mean comparison of the four packages were done for agronomic traits collected (Table 2). On the other hand, cost data were collected on labor and oxen rent, and application rates of inputs such as seed, fertilizer and pesticides were based on recommendations used for the trial. Data were initially calculated for each farmer separately and then combined across three locations. All costs and revenues were quantified based on $500 \mathrm{~m}^{2}$ and converted to hectare base; furthermore mean extrapolated to the hectare basis.

Because of the wide variety of cost concepts, it is not possible to deal with all of them in a single section; for reason only the following items was dealt with for short term benefit:
1. Variable costs
2. Total and average costs
3. Marginal costs
4. Gross margin
5. Benefits cost ratio

\subsubsection{Variable Costs}

Variable costs are a function of output and are only incurred if there is production. There is therefore a relationship between the volume of production and costs. For this study variable costs are seed, fertilizer, pesticide, wage rate, and oxen rent if production decisions have to be made on the quantities of variable inputs that must be used to maximize benefit over the short term, only variable costs are relevant since fixed costs remain constant.

\subsubsection{Total Costs}

Total costs are the sum of the total fixed and total variable costs, for this study of the short-term analysis variable only variable cost was taken.

$$
\mathrm{CpT}=\mathrm{CS}+\mathrm{CF}+\mathrm{CP}+\mathrm{CoR}+\mathrm{CL}
$$

Where,

$\mathrm{CPT}=$ cost of production of tef

$\mathrm{CS}=$ cost of seed

$\mathrm{CF}=$ cost of fertilizer

$\mathrm{CP}=$ cost of pesticides

$\mathrm{COR}=$ cost of oxen rent

$\mathrm{CL}=$ cost of labor- (which includes cost of planting, cost of fertilizer application, cost of hand weeding, cost of insecticide spraying, cost of herbicides spraying, cost of harvesting and cost of threshing).

Table 1. Treatments used for different agronomic practices for tef production.

\begin{tabular}{|c|c|c|c|c|}
\hline Parameter & Extension package & ATA package & $\begin{array}{l}\text { Research row sowing } \\
\text { recommendation }\end{array}$ & Research broad casting \\
\hline Variety & Kora & Kora & Kora & Kora \\
\hline Plot size & $25 \mathrm{~m} \times 20 \mathrm{~m}$ & $25 \mathrm{~m} \times 20 \mathrm{~m}$ & $25 \mathrm{~m} \times 20 \mathrm{~m}$ & $25 \mathrm{~m} \times 20 \mathrm{~m}$ \\
\hline $\begin{array}{l}\text { Seed-rate } \\
(\mathrm{g} / \mathrm{plot})\end{array}$ & 250 with $20 \mathrm{~cm} \mathrm{~b} / \mathrm{n}$ rows & 250 with $20 \mathrm{~cm} \mathrm{~b} / \mathrm{n}$ rows & $\begin{array}{l}750 \mathrm{~g} / \mathrm{plot} \text { with } 20 \mathrm{~cm} \mathrm{~b} / \mathrm{n} \\
\text { rows }\end{array}$ & $15 \mathrm{~kg} / \mathrm{ha}$ broad casting \\
\hline Nutrition & $\begin{array}{l}5000 \mathrm{~g} / \text { plot-NPS-(basal) } 4000 \mathrm{~g} / \text { plot- } \\
\text { UREA-as split application Package }\end{array}$ & $\begin{array}{l}5000 \mathrm{~g} / \text { plot NPS (basal), } 5000 \mathrm{~g} / \mathrm{plot} \\
\mathrm{KCL} \text { and } 4000 \mathrm{~g} / \text { plot UREA (both } \\
\text { as split application) }\end{array}$ & $\begin{array}{l}5000 \mathrm{~g} / \mathrm{plot} \text { NPS (basal) } \\
\text { and } 4000 \mathrm{~g} / \mathrm{plot} \text { UREA } \\
\text { (as split application) }\end{array}$ & $\begin{array}{l}5000 \mathrm{~g} / \mathrm{plot} \text { NPS (basal) } \\
\text { and } 4000 \mathrm{~g} / \mathrm{plot} \text { UREA } \\
\text { (as split application) }\end{array}$ \\
\hline Weed & Pallas 45 OD 20ml/plot + hand weeding & $\begin{array}{l}\text { Pallas } 45 \text { OD } 20 \mathrm{ml} / \mathrm{plot} \text { +hand } \\
\text { weeding }\end{array}$ & Hand weeding & Hand weeding \\
\hline Insecticide & karaten $20 \mathrm{ml} / 50 \mathrm{~m}^{2}$ & karaten $20 \mathrm{ml} / 500 \mathrm{~m}^{2}$ & No & No \\
\hline $\begin{array}{l}\text { Agronomic } \\
\text { management }\end{array}$ & $\begin{array}{l}\text { Tef seed planted in the furrow (furrows } \\
\text { made by the passage of the local plow as } \\
\text { rows) }\end{array}$ & $\begin{array}{l}\text { Tef seed planted in the furrow } \\
\text { (furrows made by the passage of the } \\
\text { local plow as rows) }\end{array}$ & $\begin{array}{l}\text { bed were made and rows } \\
\text { were made }\end{array}$ & Broadcasted \\
\hline
\end{tabular}

Source: stated recommendation package to verify 201 .

\subsubsection{Average Costs}

Average or unit costs are the costs per unit such as cost per kilogram or quintal, per hectare, per liter. Average variable and average total costs can, depending on the circumstances, be calculated by dividing the specific cost amount by the corresponding units.

$$
\mathrm{AVC}=T V C / \text { yield of tef }
$$

As in short run analysis focus on the operational cost analysis and the fixed cost is constant then;

$$
\mathrm{AVC}=V C / \text { yield of tef }
$$

The assumption is that for this research the fixed cost is constant and taken the variability among the costs that can be used for validation of benefits for different practices; so that ATC equals to AVC.

\subsubsection{Marginal Costs}

Marginal costs are the extra or additional costs attached to the last unit of output marginal costs are calculated by dividing the change in costs ( $\Delta$ costs) by the change in output $(\Delta$ yield), that is:

Marginal costs are only determined by an increase in variable costs. As long as marginal income is bigger than marginal costs, the benefit will be increased. 


$$
\mathrm{MC}=\frac{\Delta \mathrm{TC}}{\Delta \mathrm{Q}}
$$

Tells us how much cost rises per unit increase in yield of tef.

Marginal cost for any change in output is equal to shape of total cost curve along that interval of yield.

If the MC> AVC then the average cost is rising for kilogram of tef yield per plot or per hectare.

If the $\mathrm{MC}=\mathrm{AVC}$ then the average cost is at its lowest point. If $\mathrm{MC}<\mathrm{AVC}$ then the average cost is falling for kilogram of yield.

\subsubsection{Benefit Cost Ratio}

Benefit cost ratio is an indicator, used in cost-benefit analysis, which attempts to summarize the overall value for money of a tef production treatments. It is an important tool to assess economics of farming. It is the ratio of all net value of tef produced after deducting the costs of different inputs after their summation in the production process.

$$
\mathrm{BCR}=\frac{G B-T V C}{T V C}
$$

Where;

$\mathrm{BCR}=$ benefit cost ratio

$\mathrm{GB}=$ gross benefits

$\mathrm{TVC}=$ total variable cost

\subsubsection{Marginal Rate of Return}

Marginal rate of return technically, the marginal rate of return is the marginal return or the amount of revenue per additional item, divided by marginal cost (the cost per additional item produced). In other words, it's the amount of additional revenue that a tef production can expect to earn per each additional birr that it spends on production. Using marginal rate of return, a farmer can determine whether or not its operations has a benefit or loss.

Marginal rate of return becomes most powerful when it's used as a decision-making tool. As long as a marginal rate of return is greater than one, a farmer can make a profit by producing one additional unit. Because marginal rate of return tends to decrease as more and more units are produced, a farmer will maximize its benefits by expanding production until its marginal rate is one. Basically, this is where marginal revenue equals marginal cost $(\mathrm{MR}=\mathrm{MC})$. If a company produces beyond this point, the marginal rate of return drops below one $(\mathrm{MR}<1)$, and the company will be spending more per each additional item than it is bringing in revenue.

\section{Results and Discussion}

Research both broadcasting and row sowing recommendations gave better grain yield $1580 \mathrm{~kg} \mathrm{ha}^{-1}$ and $1550 \mathrm{kgha}^{-1}$, respectively. Similarly research row sowing and broadcasting recommendations were gave higher shoot biomass $10167 \mathrm{kgha}^{-1}$ and $10000 \mathrm{kgha}^{-1}$, respectively as compared to the rest treatments. It indicates that straw yield for the two research practices were better than the ATA and Extension package practice. The result indicates that seed rate of 10-15 $\mathrm{kgha}^{-1}$ both broad cast and row sowing gives better grain yield and aboveground biomass which is in line with the previous findings $[1,2]$. From this experiment, the two-planting methods row sowing and broadcasting revealed the same results considering the lack of appropriate planting machine for tef in Ethiopia for the time being. Therefore, we can conclude that the research recommendation and farmers practice are better for tef production than the ATA and Extension package recommendations (Table 2). According to [8]; the major drivers for productivity differences appear to be the levels of input use, so this research applied different package system of inputs for productivity and validated that the research broad casting has more advantage.

Table 2. Comparison of mean yield, shoot biomass and straw output kg per hectare.

\begin{tabular}{llll}
\hline Treatments & Yield & Shoot biomass & Straw \\
\hline Extension package & 1083 & 7583 & 6500 \\
ATA Package & 993 & 6958 & 5965 \\
Research row sowing & 1550 & 10167 & 8617 \\
Research broad casting & 1580 & 10000 & 8420 \\
\hline
\end{tabular}

Source: own data computed 2017.

On station level analysis of treatments indicate that the net revenue for treatment of extension package, ATA package, research with row planting and research with broad cast planting system show a positive return from the farming investment for production of tef; which was found 44,640.20, $31,000.20,54,164.20$ and 58,371.20 birr per hectare. The return from the treatment of research with broadcasting planting system application has 27,371 birr returns of benefits when compared to the ATA package treatment. Considering the first household on farm trial had a loss of $(19,989.80)$ and $(23,604.20)$ birr per hectare in the first and second treatments while he had a positive net return of 46,789.20 and 50,991.20 birr hectare from third and fourth treatments; which indicate that recommendation of treatment four is superior to the household on farm tef production as compare to the rest of the application modalities. On the other hand application of treatment packages on the second household on farm trial though all the management system had a positive return still research broadcasting had a good net benefit returns when equated to the rest with gross net benefit of 58,371.2 birr per hectare (Tables 3 and 4).

Based on the trial record sheet kept by researchers' close observation, the total variable costs were determined using the respective input prices. On average, the total variable cost for inputs in tef production was found 33,559.80 birr per hectare with the application of package. From the gross total variable cost the oxen rent has incurred $15,490.00 \mathrm{ha}^{-1}$ birr which is covering the $46.2 \%$ and 14840 birr for labors which $44.2 \%$ out of the gross. The total variable cost for treatment of ATA package, research with row planting and research with broad cast varies accordingly with $34,679.80,24,965.80$ and 21,043.8 birr per hectare respectively. The highest yield 
per hectare in kilogram was recorded in treatment of research with application of broadcast planting which was 1,580 while research with row planting was 1,550 ; at the same time yield for extension package and ATA package was found 1,083.33 and $993.33 \mathrm{~kg}$ per hectare; and tef market price per $\mathrm{kg}$ in the sample district was 22 birrs (Table 5).

Table 3. Benefit cost analysis for on farm extension and ATA package.

\begin{tabular}{|c|c|c|c|c|c|c|c|c|}
\hline Category & Extension & & & & ATA & & & \\
\hline Inputs/costs & DZARC & Farm $^{1}$ & Farm $^{2}$ & Average & DZARC & Farm $^{1}$ & Farm $^{2}$ & Average \\
\hline Seed & 6.50 & 6.50 & 6.50 & 6.50 & 6.50 & 6.50 & 6.50 & 6.50 \\
\hline Fertilize & 96.29 & 96.29 & 96.29 & 96.29 & 152.29 & 152.29 & 152.29 & 152.29 \\
\hline Labor-cost birr/plot & 742.00 & 742.00 & 742.00 & 742.00 & 742.00 & 742.00 & 742.00 & 742.00 \\
\hline Oxen birr/plot & 774.50 & 774.50 & 774.50 & 774.50 & 774.50 & 774.50 & 774.50 & 774.50 \\
\hline Total-inputs-cost birr/plot & $1,677.99$ & $1,677.99$ & $1,677.99$ & $1,677.99$ & $1,733.99$ & $1,733.99$ & $1,733.99$ & $1,733.99$ \\
\hline Grain-value birr/plot & $1,760.00$ & 231.00 & $1,584.00$ & $1,191.67$ & $1,419.00$ & 110.00 & $1,749.00$ & $1,092.67$ \\
\hline Straw-value birr/plot & $2,100.00$ & 447.50 & $2,327.50$ & $1,625.00$ & $1,865.00$ & 443.75 & $2,165.00$ & $1,491.25$ \\
\hline Total-Revenue birr/plot & $3,860.00$ & 678.50 & $3,911.50$ & $2,816.67$ & $3,284.00$ & 553.75 & $3,914.00$ & $2,583.92$ \\
\hline Net revenue birr/plot & $2,182.01$ & -999.49 & $2,233.51$ & $1,138.68$ & $1,550.01$ & $-1,180.24$ & $2,180.01$ & 849.93 \\
\hline Net revenue (birr/ha) & $43,640.20$ & $-19,989.80$ & $44,670.20$ & $22,773.53$ & $31,000.20$ & $-23,604.80$ & $43,600.20$ & $16,998.53$ \\
\hline
\end{tabular}

Source: own data computed 2017.

Note: Tef grain price $2200 \mathrm{birr} / \mathrm{ql}$; straw price $=500 \mathrm{birr} / \mathrm{ql}$, and plot area $=500 \mathrm{~m}^{2}$.

Table 4. Partial budget cost analysis for extension and ATA packages.

\begin{tabular}{|c|c|c|c|c|c|c|c|c|}
\hline \multicolumn{9}{|l|}{ Research recommendation } \\
\hline \multirow{2}{*}{$\begin{array}{l}\text { Category } \\
\text { Inputs/costs }\end{array}$} & \multicolumn{4}{|c|}{ Research row } & \multicolumn{4}{|c|}{ Research broad-cast } \\
\hline & DZARC & Farm $^{1}$ & Farm $^{2}$ & Average & DZARC & Farm $^{1}$ & Farm $^{2}$ & Average \\
\hline Seed & 19.50 & 19.50 & 19.50 & 19.50 & 19.50 & 19.50 & 19.50 & 19.50 \\
\hline Fertilize & 96.29 & 96.29 & 96.29 & 96.29 & 96.29 & 96.29 & 96.29 & 96.29 \\
\hline Pesticide & 0.00 & 0.00 & 0.00 & 0.00 & 0.00 & 0.00 & 0.00 & 0.00 \\
\hline Labor cost birr/plot & 583.00 & 583.00 & 583.00 & 583.00 & 386.9 & 386.90 & 386.90 & 386.90 \\
\hline Oxen birr/plot & 549.50 & 549.50 & 549.50 & 549.50 & 549.5 & 549.50 & 549.50 & 549.50 \\
\hline Yield (kg/plot) & 82.00 & 69.50 & 81.00 & 77.5 & 81.00 & 74.00 & 82.00 & 79 \\
\hline Grain value (birr/plot) & $1,804.00$ & $1,529.00$ & $1,782.00$ & 1705 & 1782.00 & 1628 & 1804.00 & 1738 \\
\hline Straw value (birr/plot) & $2,152.50$ & 2058.75 & 2251.25 & 2154.167 & 2188.75 & 1973.75 & 2152.50 & 2105 \\
\hline Total Revenue (birr/plot) & $3,956.50$ & $3,587.75$ & $4,033.25$ & 3859.167 & 3970.75 & 3601.75 & 3956.50 & 3843 \\
\hline Net revenue (birr/plot) & $2,708.21$ & $2,339.46$ & $2,784.96$ & 2610.877 & 2918.56 & $2,549.56$ & 2904.31 & 2790.81 \\
\hline Net revenue (birr/ha) & $54,164.20$ & $46,789.20$ & $55,699.20$ & $52,217.53$ & $58,371.2$ & $50,991.2$ & $58,086.2$ & $55,816.2$ \\
\hline
\end{tabular}

Note: Tef grain price $2200 \mathrm{birr} / \mathrm{ql}$; straw price $=500 \mathrm{birr} / \mathrm{ql}$, and plot area=500 $\mathrm{m}^{2}$, ql=quintal which equivalent to $100 \mathrm{k}$.

Net gross revenue with the assumption that if the farmer sells its entire yield the gain per hectare was found for each treatment- for extension package, for ATA package, research with application of row planting and research with application of broadcast planting system had gross revenue of $56,333.33,51,678.33,77,183.33$ and 76,860 birr per hectare; this state that research applying row planting has the upper rate of gross benefit while the net benefit was found $22,773.53,16,998.53,52,217.53$ and 55,816.2 birr per hectare tef production. When the treatment four is equated to treatment two the first has on average a net benefits of 38,817.67 birr per hectare for tef production (Table 5).

Table 5. Partial budget cost analysis for different recommendations per hectare based.

\begin{tabular}{llll}
\hline Category & Extension $_{\mathbf{1}}$ & ATA $_{\mathbf{2}}$ & Research row planting $_{\mathbf{3}}$ \\
\hline Inputs/costs & mean/ha & mean/ha & mean/ha \\
Seed & 130.00 & 130.00 & 390.00 \\
Fertilize & $1,925.80$ & $3,045.80$ & $1,925.80$ \\
Pesticide & $1,174.00$ & $1,174.00$ & 0.00 \\
Total Labor cost & $14,840.00$ & $14,840.00$ & $11,660.00$ \\
Plowing & $2,120.00$ & $2,120.00$ & $4,240.00$ \\
Fertilizer application. & $1,060.00$ & $1,060.00$ & $1,060.00$ \\
Weeding & $1,060.00$ & $1,060.00$ & $1,060.00$ \\
Insecticide spr. & $2,120.00$ & $2,120.00$ & $2,120.00$ \\
Herbicide spr. & $2,120.00$ & $2,120.00$ & $2,120.00$ \\
Harvesting & $2,120.00$ & $2,120.00$ & $2,120.00$ \\
Threshing & $3,180.00$ & $3,180.00$ & $3,180.00$ \\
Other tasks & 1060.00 & 1060.00 & 0.00 \\
Oxen cost & $15,490.00$ & $15,490.00$ & $10,990.00$ \\
\hline
\end{tabular}




\begin{tabular}{lllll}
\hline Category & Extension $_{\mathbf{1}}$ & ATA $_{\mathbf{2}}$ & Research row planting $_{\mathbf{3}}$ & Research broad casting $_{\mathbf{4}}$ \\
\hline Total inputs cost & $33,559.80$ & $34,679.80$ & 24965.8 & 21043.8 \\
Yield kg & $1,083.33$ & 993.33 & $1,550.00$ & 1580 \\
Grain value & $23,833.33$ & $21,853.33$ & 34100 & 34760 \\
Straw value & $32,500.00$ & $29,825.00$ & 43083.33333 & 42100 \\
Total Revenue & $56,333.33$ & $51,678.33$ & $77,183.33$ & 76,860 \\
Net revenue & $22,773.53$ & $16,998.53$ & $52,217.53$ & $55,816.2$ \\
\hline
\end{tabular}

Source: own data computed 2017

Note: Tef grain price $2200 \mathrm{birr} / \mathrm{ql}$; straw price $=500 \mathrm{birr} / \mathrm{ql}$, and plot area $=500 \mathrm{~m}^{2}$.

Rule of thumb, when the farmer output is relatively small, the average cost decreases, whereas when the output starts increasing, the average cost increases too. Farmers producing tef that seek to maximize their profits, use the average cost to determine the point that they should shut down production in the short term. Therefore, if the price of a tef is higher than the AVC of the good, it means that the firm is covering all the variable costs. In this case, farmers will continue in tef production. On the contrary, if the price they receive for tef yield is lower than the AVC, firms cease production to avoid additional variable costs. Benefit-maximizing farmer will use the AVC to determine at what point they should shut down production in the short run. If the price they are receiving for the good is more than the AVC given the output they are producing. As long as price is above the AVC and covering some of the total variable costs, you are better off continuing production. If the price falls below the $\mathrm{AVC}$, then the farmer may decide to shut down production in the short run because the price is no longer covering any portion of the all of the variable costs (Table 6).

Marginal cost the increase or decrease in the total cost of a production run for the production of additional unit of tef. The purpose of analyzing marginal cost is to determine at what point of a farmer can achieve economies of scale in tef production. The calculation is most often used among farmers as a means of isolating an optimum production level. Change of tef production from ATA package to extension package the total production cot for unit tef per hectare decreases by 12.45 birr while change of production from treatment of research with row planting can decrease cost for unit tef per hectare by 17.45 birr (Table 6). Marginal costs are variable costs consisting of all input costs in the production at the short run. In companies where average costs are fairly constant, marginal cost is usually equal to average cost. However, in small scale tef production at household level require minimum capital investment as compare to commercial investment in tef producers as a rule of thumb and have low average costs, it is comparatively very low (Table 6).

The productions of tef with a benefit-cost ratio greater than 1 have greater benefits than costs; hence they have positive net benefits. The higher the ratio, the greater the benefits relative to the costs; note that simple benefit-cost ratio is insensitive to the magnitude of net benefits and therefore may favor production with small costs and benefits over those with higher net benefits. (This problem can be eliminated by the use of the incremental benefit-cost ratio or the net present value.)

The higher the BCR the better the treatment to apply; general rule of thumb is that if the benefit is higher than the cost the production process in tef is a good investment. If a project has a BCR that is greater than 1, it indicates that benefits outweigh of the costs. Therefore, the treatment should be considered if the value is significantly greater than 1. If the BCR is equal to 1 , the ratio indicates that expected benefits equal the costs. If the production BCR is less than 1, the costs outweigh the benefits and it should not be considered. Considering Table 6 treatments of extension package and ATA package had a BCR of (0.32) and (0.51), which indicates that the two treatments cost has outweighed the benefit that show every birr of 1 cost added will result a loss of 0.32 and 0.51 birr; while applying treatment of research row planting and research broadcast planting in tef production at small scale level had a benefit of 1.09 and 1.65 birr for each 1 birr of its cost invested (Table 6). Recommendation and findings of [6] states that reducing the costs of remoteness through the construction of rural roads and increasing distribution outlets of modern inputs is likely to have a positive impact on tef productivity; this study also justifies that producers of tef in the nation are widely dispersed so input costs mark-up can vary accordingly and will have impact on the change of TVC and BCR.

Table 6. Partial budget analysis on farm trial per hectare (birr).

\begin{tabular}{llllll}
\hline Treatments & Yield $_{\mathbf{k g}}$ & TVC & AVC & MC & NB \\
\hline Extension package & $1,083.33$ & $33,559.8$ & 30.97 & - & -12.44 \\
ATA package & 993.33 & $34,679.8$ & 34.91 & -0.32 & $-16,998.53$ \\
Research row planting Package & 1,550 & $24,965.8$ & 16.09 & -0.51 \\
Research broadcast planting & 1,580 & $21,043.8$ & 13.32 & -130.73 & $52,217.53$ \\
\hline
\end{tabular}

Source: own data computed 2017.

Note: $\mathrm{TVC}=$ total variable cost $($ variable cost $)=$ total cost.

$\mathrm{AVC}=$ average variable cost.

$\mathrm{MC}=$ marginal cost.

$\mathrm{NB}=$ net benefit.

$\mathrm{BCR}=$ benefit cost ratio. 


\section{Conclusions and Recommendations}

The objective of this on farm experiment was to validate and recommend on farm economically superior technology packages to small scale farmers who are engaged in the tef production. keeping constant all other factors that can create a variation among smallholder producers and soil type variability the result indicates that research package on broadcast planting and raw planting systems were found to be superior in the potential producer of sample selected districts research both broadcasting and row sowing recommendations gave better grain yield $1580 \mathrm{kgha}^{-1}$ and $1550 \mathrm{kgha}^{-1}$, respectively. Whereas ATA package and extension package recommendations gave grain yield $993 \mathrm{kgha}^{-1}$ and $1083 \mathrm{kgha}^{-1}$, respectively. Similarly research row sowing and broadcasting recommendations were gave higher above ground biomass $10167 \mathrm{kgha}^{-1}$ and $10000 \mathrm{kgha}^{-1}$, respectively as compared to the ATA and Extension package practice. The result indicates that seed rate of 10$15 \mathrm{kgha}^{-1}$ both for broad cast and row sowing gives better grain yield and shoot biomass providing the highest return with marginal rate of return of, whereas ATA package was found to be the least economically viable treatment having minimum MRR. However, the profitability of the four treatment packages varied across the three farm trials. The variation could be both due to the treatments and location specific condition with soil type variability or other different heterogeneous factors; yet the research packages with two different planting methods were found high yielding with low total variable cost incurred and high benefit cost ratio as compared to other treatments. So; it was found that the research package with broadcast planting method of tef was more profitable and followed by the raw planting methods when compared to the extension and ATA packages. Intervention and scaling up of the two methods of planting in research package can benefits farmers to gain good returns as compared to others for profitability and to increase the market supply or sustaining consumption of the household. This study recommends a research package that reduces the TVC can increase profitability; which [6]) also stated innovations that reduce labor requirements for growing tef might satisfy the increasing demands for tef at an affordable price.

\section{Competing Interests}

Authors have declared that they have no competing interests.

\section{References}

[1] Abraha Arefaine, Daniel Adhanom, Negasi Tekeste. (2020) "Response of Teff (Eragrostis tef (Zucc) Trotter) to Seeding Rate and Methods of Sowing on Yield and Yield Attributes in a Subhumid Environment, Northern Ethiopia", International Journal of Agronomy, vol. 2020, Article ID 1516790, 7 pages, 2020. https://doi.org/10.1155/2020/1516790.
[2] Abraha Reda, Nigussie Dechassa, Kebebew Assefa. (2018). Evaluation of Seed Rates and Sowing Methods on Growth, Yield and Yield Attributes of Tef [Eragrostis tef (Zucc.) Trotter] in Ada District, East Shewa, Ethiopia. AmericanEurasian J. Agric. \& Environ. Sci., 18 (1): 34-49, 2018. DOI: 10.5829/idosi.aejaes.2018.34.49.

[3] Abera, H. B. (2008). Adoption of improved tef and wheat production technologies in crop-livestock mixed systems in northern and western Shewa zones of Ethiopia (Doctoral dissertation, University of Pretoria.

[4] Andersen, R. and Winge, T., 2012. The Access and BenefitSharing Agreement on Tef Genetic Resources. FNI Report, $6 / 2012$.

[5] Cafer, A., \& Rikoon, S. (2017). Coerced agricultural modernization: a political ecology perspective of agricultural input packages in South Wollo, Ethiopia. Journal of Rural Social Sciences, 32 (1), 6.

[6] CSA. 2015. Central Statistical Agency. The Federal Democratic Republic of Ethiopia, Central Statistical Agency (CSA), Agricultural Sample Survey 2014/15 (2007 E. C.), Volume I, Report on Area and Production of Major Crops (Private Peasant Holdings, Meher Season), Statistical Bulletin 278, May 2015, Addis Ababa, Ethiopia.

[7] Ethiopian Nutrition Survey. 1959. A Report by the InterDepartmental Committee on Nutrition for National Defense. September 1959.

[8] Hailu, G., Weersink, A., Minten, B.; Determinants of the Productivity of Tef in Ethiopia (2017) European Journal of Development Research, 29 (4), pp. 866-892.

[9] Heiniger, U.; Tef (Eragrostis tef (Zucc.) Trotter) - Gluten-free grain from Ethiopia [Tef (Eragrostis tef (ZUCC.) TROTTER)glutenfreies Getreide aus äthiopien] (2016) Schweizerische Zeitschrift fur GanzheitsMedizin, 28 (5), pp. 281-292.

[10] Kebebew Assefa, Sherif Aliye, Getachew Belay, Gizaw Metaferia, Hailu Tefera \& Mark E. Sorrells (2011) Quncho: the first popular tef variety in Ethiopia, International Journal of Agricultural Sustainability, 9: 1, 25-34.

[11] Seboka, B., \& Deressa, A. (1999). Validating farmers' indigenous social networks for local seed supply in Central Rift Valley of Ethiopia. The Journal of Agricultural Education and Extension, 6 (4), 245-254.

[12] Seyfu Ketema. 1997. Tef. Eragrostis tef (Zucc.) Trotter. Promoting the conservation and use of underutilized and neglected crops. 12. Institute of Plant Genetics and Crop Plant Research, Gatersleben/International Plant Genetic Resources Institute, Rome, Italy; Washington, D. C.

[13] Spaenij-Dekking, L, Kooy-Winkelaar, Y, Koning, F. 2005. The Ethiopian cereal tef in celiac disease. New England Journal of Medicine 353: 1748-1749.

[14] Worku, I., Dereje, M., Berhane, G., Minten, B. and Taffesse A. L., 2014. Tef and its Role in the Agricultural and Food Economy. (Unpublished). 